\title{
PENGARUH LAMA PRAKTIK DAN PENGETAHUAN DOKTER PRAKTIK MANDIRI TERHADAP PENEMUAN TERDUGA TUBERCULOSIS ANAK DI WILAYAH SURABAYA UTARA
}

\author{
Fildah Alyani ${ }^{1}$, Chatarina Umbul W' \\ ${ }^{1}$ RSUD Panembahan Senopati Bantul, Daerah Istimewah Yogyakarta \\ ${ }^{2}$ Departemen Epidemiologi, Fakultas Kesehatan Masyarakat, Universitas Airlangga \\ Alamat Korespondensi: Fildah Alyani \\ Email: fildaalyani94@gmail.com
}

\begin{abstract}
Indonesia is the second most populated country with TB in the world. The proportion of Tuberculosis (TB) and adult tuberculosis cases in Indonesia is increasing every year. East Java is ranked second in TB cases in Indonesia. Surabaya is the most common city of TB cases. Therefore, WHO recommends the DOTS program for $T B$ control that focuses on finding and healing TB patients, especially TB children. However, the implementation of this program has an imbalance in the number of adult TB findings and child TB. Factors that influence the discovery of TB suspected children are the length of practice and knowledge of Independent Practice Doctors (DPM). The purpose of this study was to analyze the effect of long time practice and knowledge of Practice Doctor Mandiri on TB child suspected finding. This research is an umbrella research of operational research of child TB treatment network with cross sectional study design. The sampling technique is simple random sampling with the amount of 42 people. Data collection is secondary data using data collection sheets. Data analysis using logistic regression. The result shows that there is a long effect of practice on TB children with $p$ value 0,015<0,05 and OR value is 8,182. Independent Practice Physician Knowledge has no effect on TB children with $p$ value 0,297>0,05 and OR 2,125. There is a need for regular socialization of child TB, especially the management of child $T B$ and the commitment of the Independent Practice Doctor to the discovery of TB suspected.
\end{abstract}

Keywords: TB child, independent practice doctor, duration of practice, knowledge

\begin{abstract}
ABSTRAK
Indonesia merupakan negara peringkat kedua terbanyak penderita TB di dunia. Jumlah proporsi kasus TB dewasa dan TB anak di Indonesia meningkat setiap tahun. Jawa Timur menduduki peringkat kedua kasus TB di Indonesia. Surabaya merupakan kota yang paling banyak ditemukannya kasus TB. Oleh karena itu, WHO merekomendasikan program DOTS untuk penanggulangan TB yang berfokus pada penemuan dan penyembuhan penderita TB terutama TB anak. Namun, dalam pelaksanaan program ini terdapat ketimpangan jumlah temuan TB dewasa dan TB anak. Faktor yang mempengaruhi penemuan terduga TB anak adalah lama praktik dan pengetahuan Dokter Praktik Mandiri (DPM). Tujuan penelitian ini untuk menganalisis pengaruh lama praktik dan pengetahuan Dokter Praktik Mandiri terhadap penemuan terduga TB anak. Jenis penelitian ini merupakan observasional analitik dengan desain studi cross sectional. Teknik pengambilan sampel adalah simple random sampling dengan jumlah 42 orang. Pengambilan data berupa data sekunder menggunakan lembar pengumpul data. Analisis data menggunakan regresi logistik. Didapatkan hasil ada pengaruh lama praktik terhadap penemuan terduga TB anak dengan nilai $p$ 0,015 (nilai $p<0,05$ ) dan nilai $O R \quad 8,182$ dengan 95\% CI $(1,495$ 44,772). Pengetahuan Dokter Praktik Mandiri tidak berpengaruh terhadap penemuan terduga TB anak dengan nilai $p 0,297$ (nilai $p>0,05)$ dan nilai $O R 2,125$ dengan $95 \% C I(0,515-8,770)$. Perlu adanya sosialisasi yang berkala tentang TB anak, terutama penatalaksanaan TB anak dan peningkatan komitmen Dokter Praktik Mandiri dalam penemuan terduga TB anak.
\end{abstract}

Kata kunci: TB anak, dokter praktik mandiri, lama praktik, pengetahuan

\section{PENDAHULUAN}

Tuberkulosis (TB) merupakan penyakit menular yang disebabkan oleh bakteri Mycobacterium tuberculosis. Pada umumnya, bakteri ini menyerang paru. Namun, bakteri ini juga dapat menyerang bagian tubuh lainnya, seperti: ginjal, tulang dan otak. Penyakit TB paru ditularkan oleh penderita TB BTA positif. Penularan 
melalui udara dalam bentuk droplet (percikan) pada saat penderita batuk ataupun bersin sehingga infeksi penularan terjadi ketika orang yang sehat menghirup droplet (percikan ludah) melalui saluran pernafasan mereka (Kemenkes RI, 2010).

Sebagian besar penderita penyakit tuberkulosis diderita oleh orang dewasa. Namun, tidak menutup kemungkinan penyakit tersebut juga diderita oleh anakanak. Menurut Global Tuberculosis Report (2015), WHO telah menemukan sebesar 6,3\% kasus baru pada anak dengan usia kurang dari 15 tahun. WHO memperkirakan sebanyak 1,2 juta anak di bawah usia 5 tahun telah terkonfirmasi bakteriologis diantara pasien terduga TB, sedangkan yang dilaporkan telah melakukan pengobatan sesuai kebijakan yang berlaku pada usia tersebut sebanyak $87.236(7,1 \%)$.

Penyakit tuberkulosis merupakan salah satu masalah utama penyakit menular di negara berkembang, termasuk Indonesia. Indonesia berada diurutan kedua setelah India dengan jumlah penderita sebesar $10 \%$ dari jumlah total pasien TB di dunia. WHO menyatakan terdapat peningkatan insidens pada seluruh tipe TB dari tahun 2013 ke tahun 2014. Awalnya, seluruh tipe TB sebanyak 183 per 100.000 penduduk menjadi sebanyak 399 per 100.000 penduduk (WHO, 2015).

Insiden TB Anak di Indonesia diperkirakan sebanyak 75 per 100.000 penduduk yang terbagi menjadi 39 per 100.000 pada anak laki-laki dan 36 per 100.000 pada anak perempuan (WHO, 2015). Berdasarkan laporan dari Kemenkes RI (2016), proporsi kasus tuberkulosis anak mengalami peningkatan dari tahun 2014 ke tahun 2015. Proporsi kasus tuberkulosis anak semula sebesar 7,1\% menjadi $8,59 \%$.

Menurut data profil kesehatan Indonesia (2016), Jawa Timur menempati urutan kedua sebagai Provinsi dengan penyumbang penderita TB terbanyak di Indonesia setelah Jawa Barat. Pada tahun
2015, jumlah penderita dewasa kasus baru BTA positif di Jawa Timur sebanyak 41.523, sedangkan jumlah penderita anak kasus baru BTA positif di Provisinsi Jawa Timur sebanyak 2.563 (Kemenkes RI, 2016).

Penderita TB di Jawa Timur banyak ditemukan di Kota Surabaya. Surabaya menempati urutan pertama sebagai Kota penyumbang penderita TB terbanyak di Jawa Timur dengan jumlah kasus baru BTA positif sebanyak 2.054 penderita, diikuti Kabupaten Jember sebanyak 2.070 penderita dan Kabupaten Pasuruan sebanyak 1.132 penderita (Dinkes Provinsi Jawa Timur, 2014).

Namun, berdasarkan jumlah kasus TB anak, urutan pertama diduduki oleh Kabupaten Lamongan sebesar 14,37\%, diikuti Kota Kediri sebesar 13,36\% dan Kabupaten Ponorogo sebesar 11,95\%. Jumlah kasus TB anak di Surabaya hanya sebesar 1,57\% (Dinkes Provinsi Jawa Timur, 2014). Meskipun jumlah kasus TB anak di Surabaya tergolong rendah, tetapi Surabaya merupakan Kota dengan penderita TB terbanyak di Jawa Timur sehingga risiko penularan penyakit $\mathrm{TB}$ cukup tinggi.

Semakin meningkatnya jumlah kasus TB di Indonesia, World Health Organization (WHO) dan International Union Against $T B$ and Lung Disease (IUATLD) merekomendasikan program yang disebut Directly Observed Treatment Short Course (DOTS) pada awal tahun 1990. Program DOTS digunakan sebagai strategi dalam penanggulangan TB dengan berfokus pada penemuan dan penyembuhan penderita TB. Pelaksanaan program ini dengan cara memutuskan rantai penularan $\mathrm{TB}$ sehingga angka insidens kasus TB di masyarakat diharapkan akan menurun (Kemenkes RI, 2011).

Selama pelaksanaan program DOTS terdapat ketimpangan cakupan temuan TB dewasa dan TB anak. Jumlah kasus TB anak jauh lebih sedikit daripada 
jumlah kasus TB dewasa. Menurut Kartasasmita (2009), kesulitan dalam konfirmasi diagnosis TB anak dapat menjadi salah satu penyebab rendahnya cakupan TB anak. Hal ini mengakibatkan penanganan TB anak cenderung terabaikan sehingga sampai beberapa waktu TB anak tidak termasuk masalah prioritas kesehatan masyarakat di berbagai negara, termasuk di Indonesia.

Organisasi TB Indonesia (2017), juga menyebutkan rendahnya cakupan penemuan TB anak di Indonesia disebabkan oleh beberapa faktor yaitu sulitnya mendiagnosis TB pada anak. Kemampuan anak dalam berdahak dan perlunya kombinasi gambaran klinis serta pemeriksaan penunjang yang relevan berpengaruh dalam mendiagnosis TB anak. Faktor lain yang menjadi penyebab adalah tidak diketahuinya beban kasus TB anak di dunia. Hal ini diakibatkan tidak adanya alat diagnostik yang "child-friendly" serta tidak adekuatnya sistem pencatatan dan pelaporan kasus TB pada anak.

Dokter Praktik Mandiri (DPM) berperan dalam penemuan terduga TB anak. Keberhasilan penemuan terduga TB anak yang dilakukan oleh Dokter Praktik Mandiri (DPM) dapat dipengaruhi oleh beberapa faktor diantaranya lama praktik dan pengetahuan Dokter Praktik Mandiri (DPM). Rentang waktu praktik yang lebih lama akan memungkinkan Dokter Praktik Mandiri (DPM) memiliki pengalaman dan kentrampilan dalam melaksanakan peran sehingga dapat menjamin produktifitas kerja. Hal ini sejalan dengan penelitian yang dilakukan oleh Sumartini (2014) yang menyatakan bahwa terdapat pengaruh yang signifikan antara lama kerja dengan peran petugas kesehatan dalam penemuan kasus TB di Kota Mataram.

Faktor lain yang berperan dalam penemuan terduga TB anak adalah pengetahuan Dokter Praktik Mandiri (DPM). Secara umum, tingkat pengetahuan Dokter Praktik Mandiri (DPM) yang tergolong baik maka menunjukkan tingkat pemahaman Dokter Praktik Mandiri (DPM) dalam menerima informasi juga baik. Oleh karena itu, semakin baik pengetahuan Dokter Praktik Mandiri (DPM) berkaitan tentang TB anak diharapkan akan semakin banyak pula cakupan temuan penderita TB anak di Kota Surabaya. Penelitian yang dilakukan oleh Mahendradhata, dkk (2007) yang menyatakan bahwa sebanyak 58 dari 87 dokter umum $(66,7 \%)$ memiliki pengetahuan kurang tentang DOTS. Penelitian lain yang juga dilakukan oleh Mahendradhata (2011) dalam Departemen Kesehatan RI (2012) menyatakan bahwa tidak seluruh dokter pernah menjumpai suspek TB anak ataupun kasus TB di tempat praktik swasta. Bahkan, banyak Dokter Praktik Swasta (DPS) yang belum pernah mendapatkan informasi mengenai DOTS dan scoring chart TB anak. DPS cenderung meresepkan obat lepas dan Obat Anti Tuberculosis (OAT) lini ke-2 untuk kasus TB baru serta tidak melaporkan pasien TB tersebut ke Dinas Kesehatan.

Berdasarkan permasalahan di atas, peneliti tertarik untuk melakukan penelitian mengenai pengaruh karakteristik dan pengetahuan Dokter Praktik Mandiri (DPM) tentang TB anak terhadap tindakan penemuan penderita terduga TB anak di Wilayah Surabaya Utara. Hal ini karena Surabaya Utara merupakan wilayah kantong TB di Surabaya. Berdasarkan data profil Dinas Kesehatan Kota Surabaya (2015), jumlah kasus TB dewasa sebanyak 947 kasus dan TB anak sebanyak 1 kasus. Penelitian ini bertujuan untuk mengidentifikasi karakteristik, tingkat pengetahuan, dan tindakan penemuan penderita terduga TB anak oleh Dokter Praktik Mandiri (DPM), serta menganalisis pengaruh karakteristik dan pengetahuan Dokter Praktik Mandiri (DPM) terhadap tindakan penemuan penderita terduga TB anak. 


\section{METODE PENELITIAN}

Penelitian ini adalah penelitian observasional analitik dengan desain penelitian yang digunakan adalah studi cross sectional. Lokasi penelitian di wilayah Surabaya Utara dengan waktu penelitian dilaksanakan mulai bulan Juni sampai dengan bulan November 2017. Waktu pengambilan data dilaksanakan pada bulan September sampai dengan bulan Oktober 2017.

Populasi dalam penelitian ini adalah seluruh Dokter Praktik Mandiri (DPM) yang memenuhi kriteria inklusi penelitian yang seluruhnya berjumlah sebanyak 75 orang. Sampel penelitian ini adalah sebagian Dokter Praktik Mandiri (DPM) yang memenuhi kriteria inklusi penelitian. Adapun kriteria inklusi dalam penelitian ini adalah Dokter Praktik Mandiri (DPM) yang memiliki Surat Tanda Registrasi (STR), Surat Ijin Praktik (SIP) dan telah berpraktik di wilayah Surabaya Utara minimal satu tahun. Kriteria eksklusi penelitian ini adalah penemuan terduga TB anak di luar praktik mandiri dokter tersebut.

Besar sampel dalam penelitian ini dihitung menggunakan rumus Lemeshow (1997), dan didapatkan besar sampel penelitian sebanyak 42 orang. Teknik pengambilan sampel menggunakan teknik simple random sampling. Langkah pertama yang dilakukan dalam pengambilan sampel yaitu mendaftar seluruh nama dari seluruh anggota populasi yang telah ditetapkan yaitu sebanyak 75 orang. Selanjunya, membuat tabel random untuk menentukan sampel yang akan diambil, kemudian dari tabel random tersebut didapatkan sampel yang dibutuhkan sesuai perhitungan yang dilakukan yaitu sebanyak 42 orang.

Variabel terikat dalam penelitian ini adalah penemuan penderita terduga TB anak. Sedangkan, variabel bebas dalam penelitian ini adalah lama pratik dan pengetahuan Dokter Praktik Mandiri (DPM). Seluruhnya merupakan data sekunder yang diambil menggunakan lembar pengumpul data.

Analisis data yang dilakukan terdiri dari dua analisis, yaitu analisis univariat untuk mengetahui distribusi frekuensi karakteristik, tingkat pengetahuan, penemuan terduga TB anak oleh Dokter Praktik Mandiri (DPM). Analisis yang kedua adalah analisis bivariat menggunakan Uji regresi logistik dengan tingkat signifikansi $\alpha=0,05$ untuk mengetahui pengaruh antara variabel bebas dan terikat.

\section{HASIL}

\section{Karakteristik Dokter Praktik Mandiri}

Pada Tabel 1 dapat diketahui bahwa sebagian besar responden berusia antara 36-45 tahun sebanyak 14 orang $(33,3 \%)$. Dilihat dari tingkat pendidikan Dokter Praktik Mandiri (DPM), dapat diketahui bahwa responden terbanyak memiliki kualifikasi tingkat pendidikan sebagai dokter umum sebanyak 40 orang $(95,2 \%)$. Sedangkan, terdapat 2 orang lainnya $(4,8 \%)$ memiliki kualifikasi tingkat pendidikan sebagai dokter spesialis patologi klinik.

Berdasarkan lama waktu praktik responden di wilayah Surabaya Utara, sebagian besar responden memiliki lama praktik lebih besar sama dengan 10 tahun yaitu sebanyak 22 orang $(52,4 \%)$. Rata-rata lama praktik responden di wilayah Surabaya Utara yaitu selama 13 tahun dengan waktu praktik terlama 49 tahun dan waktu praktik tersingkat 1 tahun. Distribusi responden terkait riwayat penemuan TB anak dapat diketahui bahwa responden terbanyak tidak pernah menemukan TB anak selama tiga bulan terakhir yaitu sebanyak 34 orang $(81,0 \%)$.

Berdasarkan riwayat responden dalam mengikuti kegiatan sosialisasi TB DOTS dapat diketahui bahwa sebagian besar responden pernah mengikuti sosialisasi TB DOTS yaitu sebanyak 29 orang $(69,0 \%)$. Penyelenggara kegiatan sosialisasi TB DOTS terbanyak pada 
Dokter Praktik Mandiri (DPM) di wilayah Surabaya Utara adalah Dinas Kesehatan Kota (DKK) sebesar 23,8\%, selanjutnya diikuti oleh Dinas Kesehatan Provinsi dan Rumah Sakit dengan masing-masing sebesar 11,9\% (Sugiyono, 2015).

Pada Tabel 1 akan disajikan hasil penelitian mengenai karakteristik Dokter Praktik Mandiri (DPM) di wilayah Surabaya Utara sebagai berikut.

Tabel 1.Distribusi Responden Berdasarkan Karakteristik di Wilayah Surabaya Utara Tahun 2017

\begin{tabular}{|c|c|c|}
\hline $\begin{array}{c}\text { Karakteristik } \\
\text { Dokter Praktik } \\
\text { Mandiri }\end{array}$ & Frekuensi & $\%$ \\
\hline \multicolumn{3}{|l|}{ Usia } \\
\hline $26-35$ & 9 & 21,4 \\
\hline $36-45$ & 14 & 33,3 \\
\hline $46-55$ & 12 & 28,6 \\
\hline $56-65$ & 2 & 4,8 \\
\hline$>65$ & 5 & 11,9 \\
\hline Total & 42 & 100,0 \\
\hline \multicolumn{3}{|c|}{ Tingkat Pendidikan } \\
\hline Dokter Umum & 40 & 95,2 \\
\hline Dokter Spesialis & 2 & 4,8 \\
\hline Total & 42 & 100,0 \\
\hline \multicolumn{3}{|c|}{ Lama Praktik Mandiri } \\
\hline$<10$ tahun & 20 & 47,6 \\
\hline$\geq 10$ tahun & 22 & 52,4 \\
\hline Total & 42 & 100,0 \\
\hline \multicolumn{3}{|c|}{ Riwayat Penemuan TB Anak } \\
\hline Tidak Pernah & 34 & 81,0 \\
\hline Pernah & 8 & 19,0 \\
\hline Total & 42 & 100,0 \\
\hline \multicolumn{3}{|c|}{ Riwayat Sosialisasi TB DOTS } \\
\hline Tidak Pernah & 13 & 31,0 \\
\hline Pernah & 29 & 69,0 \\
\hline Total & 42 & 100,0 \\
\hline $\begin{array}{c}\text { Sumber: Data OR } \\
\text { Laksana TB } \\
\text { Tahun } 2017\end{array}$ & $\begin{array}{l}\text { embangun } \\
\text { nak Melalui }\end{array}$ & $\begin{array}{l}\text { aring Tata } \\
\text { eran DPM }\end{array}$ \\
\hline
\end{tabular}

\section{Pengetahuan Dokter Praktik Mandiri}

Tabel 2.Distribusi Responden Berdasarkan Pengetahuan di Wilayah Surabaya Utara Tahun 2017

\begin{tabular}{lcc}
\hline $\begin{array}{c}\text { Pengetahuan } \\
\text { Dokter Praktik } \\
\text { Mandiri }\end{array}$ & Frekuensi & $\%$ \\
\hline Kurang Baik & 21 & 50,0 \\
Baik & 21 & 50,0 \\
\hline Total & 42 & 100,0 \\
\hline $\begin{array}{c}\text { Sumber: Data OR } \\
\text { Laksana TB Anbangun Jejaring Tata } \\
\text { Tahun 2017 }\end{array}$ & & \\
&
\end{tabular}

Pengetahuan Dokter Praktik Mandiri (DPM) terbagi menjadi dua kategori, yaitu pengetahuan baik dan kurang baik. Pengetahuan responden dikatakan baik apabila respoden mampu menjawab pertanyaan dengan benar lebih besar 75\% dan dikatakan kurang baik apabila responden mampu menjawab pertanyaan kurang dari sama dengan $75 \%$ dari seluruh pertanyaan tentang TB anak. Data mengenai pengetahuan Dokter Praktik Mandiri (DPM) dapat dilihat pada tabel 2.

Berdasarkan Tabel 2 dapat diketahui bahwa jumlah responden yang memiliki pengetahuan baik sebanyak 21 orang $(50 \%)$. Pengetahuan responden diukur berdasarkan 11 aspek pengetahuan tentang TB anak meliputi tanda dan gejala terduga TB anak, kriteria penetapan terduga TB anak, penegakkan diagnosis TB anak menurut WHO dan petunjuk teknis manajemen TB anak, cara mendapatkan sampel sputum pada anak, sistem skoring, waktu pengobatan TB anak, regimen OAT anak, cara pemantauan pengobatan TB anak, waktu penggunaan INH, dan kewajiban Dokter Praktik Mandiri (DPM) dalam pengendalian TB anak.

\section{Penemuan Terduga TB Anak}

Berikut ini hasil yang diperoleh dari penemuan terduga TB anak yang 
dilakukan oleh Dokter Praktik Mandiri (DPM) dapat dilihat pada Tabel 3.

Tabel 3.Distribusi Responden Berdasarkan Penemuan Terduga TB Anak di Wilayah Surabaya Utara Tahun 2017

\begin{tabular}{lcc}
\hline $\begin{array}{c}\text { Penemuan } \\
\text { Terduga TB } \\
\text { Anak }\end{array}$ & Frekuensi & $\%$ \\
\hline $\begin{array}{l}\text { Tidak } \\
\text { Menemukan }\end{array}$ & 31 & 73,8 \\
\hline Menemukan & 11 & 26,2 \\
\hline Total & 42 & 100,0 \\
\hline $\begin{array}{l}\text { Sumber: Data OR } \\
\text { Laksana TB } \\
\text { Tahun 2017 }\end{array}$ & & \\
Anak Melangun Jejaring Tata \\
\end{tabular}

Berdasarkan Tabel 3 dapat diperoleh hasil bahwa sebagian besar Dokter Praktik Mandiri (DPM) tidak berhasil dalam menemukan terduga TB anak yaitu sebanyak 31 orang $(73,8 \%)$. Dokter Praktik Mandiri (DPM) yang berhasil menemukan terduga TB anak sebanyak 11 orang $(26,2 \%)$. Sebelas orang yang ditemukan TB terdapat 1 dokter yang berhasil menemukan 6 orang terduga TB anak.

\section{Pengaruh Lama Praktik Mandiri terhadap Penemuan Terduga TB Anak}

Tabel 4. Pengaruh Lama Praktik Mandiri terhadap Penemuan Terduga TB Anak di Wilayah Surabaya Utara Tahun 2017

\begin{tabular}{lcccc}
\hline \multirow{2}{*}{$\begin{array}{c}\text { Lama } \\
\text { Praktik }\end{array}$ Mandiri } & \multicolumn{4}{c}{$\begin{array}{c}\text { Penemuan Terduga } \\
\text { TB Anak }\end{array}$} \\
\cline { 2 - 5 } & $\begin{array}{c}\text { Tidak } \\
\text { Menemukan }\end{array}$ & Menemukan \\
\cline { 2 - 5 } & $\mathbf{N}$ & $\mathbf{\%}$ & $\mathbf{n}$ & $\mathbf{\%}$ \\
\hline$<10$ tahun & 2 & 9,1 & 20 & 64,5 \\
$\geq 10$ tahun & 9 & 45,0 & 11 & 55,0 \\
\hline OR & $=8,182$ & $p=0,015$ \\
$95 \%$ CI & $=1,495$ & $-44,772$ & \\
Sumber: Data & OR & Membangun Jejaring & Tata \\
Laksana TB & Anak Melalui & Peran & DPM \\
Tahun 2017 &
\end{tabular}

Berikut ini disajikan hasil tabulasi silang pengaruh lama praktik mandiri terhadap penemuan terduga TB anak yang dapat dilihat pada Tabel 4. Berdasarkan Tabel 4 dapat diketahui bahwa keberhasilan penemuan terduga TB anak sebagian besar dilakukan oleh Dokter Praktik Mandiri (DPM) yang memiliki lama praktik kurang dari sama dengan 10 tahun sebanyak 20 orang (64,5\%).

Nilai Odds ratio sebesar 8,182 (tingkat signifikansi sebesar 95\%, Confidence interval $1,495<O R<44,772$ ) yang artinya Dokter Praktik Mandiri (DPM) yang memiliki lama praktik kurang dari 10 tahun memiliki risiko tidak menemukan terduga TB anak 8,182 kali dibandingkan Dokter Praktik Mandiri (DPM) yang memiliki lama praktik 10 tahun ke atas.

Nilai Odds ratio (OR) bermakna karena 95\% Confidence Interval tidak melewati angka 1,00 yang artinya ada perbedaan Dokter Praktik Mandiri (DPM) dalam melakukan penemuan terduga TB anak berdasarkan lama praktik Dokter Praktik Mandiri (DPM) di wilayah Surabaya Utara. Hasil Uji statistik menggunakan Uji regresi logistik diperoleh nilai $p=0,015$ yangmana nilai $p<0,05$. Hal ini menunjukkan ada pengaruh antara lama praktik mandiri (DPM) di wilayah Surabaya Utara terhadap penemuan terduga TB anak.

\section{Pengaruh Pengetahuan Dokter Praktik Mandiri terhadap Penemuan Terduga TB Anak}

Hasil tabulasi silang keberhasilan penemuan terduga TB anak oleh Dokter Praktik Mandiri (DPM) berdasarkan pengetahuan tentang TB anak dapat dilihat pada tabel 5. Berdasarkan Tabel 5 dapat diketahui bahwa keberhasilan penemuan terduga TB anak sebagian besar dilakukan oleh Dokter Praktik Mandiri (DPM) yang memiliki pengetahuan kurang baik yaitu sebanyak 17 orang $(81,0 \%)$. 
Tabel 5. Pengaruh Pengetahuan Dokter Praktik Mandiri terhadap Penemuan Terduga TB Anak di Wilayah Surabaya Utara Tahun 2017

\begin{tabular}{|c|c|c|c|c|}
\hline \multirow{3}{*}{$\begin{array}{l}\text { Hasil } \\
\text { Tahu }\end{array}$} & \multicolumn{4}{|c|}{$\begin{array}{c}\text { Penemuan Terduga } \\
\text { TB Anak }\end{array}$} \\
\hline & \multicolumn{2}{|c|}{$\begin{array}{c}\text { Tidak } \\
\text { Menemukan }\end{array}$} & \multicolumn{2}{|c|}{ Menemukan } \\
\hline & $\mathbf{n}$ & $\%$ & $\mathbf{n}$ & $\%$ \\
\hline Kurang & 4 & 19,0 & 17 & 81,0 \\
\hline Baik & 7 & 33,3 & 14 & 66,7 \\
\hline $95 \%$ & & $15-8$ & & 2,125 \\
\hline
\end{tabular}

Sumber: Data OR Membangun Jejaring Tata Laksana TB Anak Melalui Peran DPM Tahun 2017

Nilai Odds ratio sebesar 2,125 (tingkat signifikansi sebesar 95\%, Confidence interval $0,515<O R<8,770$ ) yang artinya Dokter Praktik Mandiri (DPM) yang berpengetahuan kurang baik memiliki risiko tidak menemukan terduga TB anak 2,125 kali dibandingkan Dokter Praktik Mandiri (DPM) yang berpengetahuan baik.

Nilai Odds ratio (OR) tidak bermakna karena 95\% Confidence Interval melewati angka 1,00 maka artinya ada tidak ada perbedaan Dokter Praktik Mandiri (DPM) dalam melakukan penemuan terduga TB anak berdasarkan kategori pengetahuan. Hasil Uji statistik menggunakan Uji regresi logistik diperoleh nilai $p=0,297$, dengan nilai $p$ value $>$ 0,05 . Hal ini menunjukkan bahwa tidak ada pengaruh antara pengetahuan Dokter Praktik Mandiri (DPM) tentang TB anak terhadap penemuan terduga TB anak.

\section{PEMBAHASAN}

\section{Gambaran Karakteristik Responden}

Hasil penelitian diperoleh informasi bahwa usia responden terbanyak dalam rentang usia 36-45 tahun yang merupakan usia produktif yaitu sebanyak 14 orang. Hal ini memungkinkan responden untuk lebih energik dalam bekerja sehingga lebih mampu untuk menemukan terduga TB anak. Hasil penelitian ini didukung dengan penelitian Suparyanto (2005) yang menyatakan bahwa tenaga kesehatan dengan rentang usia antara 20 sampai dengan 50 tahun memiliki masa usia produktif yang masih cukup lama sehingga memungkinkan tenaga kesehatan untuk dapat meningkatkan kinerjanya.

Menurut Suparyanto (2005), pendidikan merupakan kegiatan yang bertujuan untuk memperbaiki kemampuan yang ada pada diri individu berupa ilmu dan ketrampilan baru yang akan dimilikinya. Dilihat dari distribusi tingkat pendidikan, sebagian besar responden memiliki kualifikasi tingkat pendidikan sebagai dokter umum sebanyak 40 orang. Hal ini karena terbatasnya jumlah dokter spesialis, terutama dokter spesialis anak dan dokter spesialis paru (Mubarak, 2007).

Dilihat dari distribusi frekuensi lama praktik mandiri dapat diketahui bahwa sebagian besar Dokter Praktik Mandiri (DPM) memiliki lama praktik lebih dari 10 tahun sebanyak 22 orang. Responden dengan lama praktik di wilayah Surabaya Utara lebih dari 10 tahun dianggap memiliki pengalaman lebih dalam memahami situasi dan kondisi wilayah tersebut sehingga cenderung mampu untuk lebih banyak terlibat dalam upaya penemuan terduga TB anak. Pernyataan ini didukung oleh Suparyanto (2005) yang menyatakan bahwa petugas kesehatan yang memiliki masa kerja cukup lama (di atas 10 tahun) dianggap lebih berpengalaman dalam tugas dan perannya sebagai petugas program penanggulangan dan pencegahan TB (P2TB) sehingga penanggulangan penyakit TB di masyarakat dapat berjalan dengan baik.

Berdasarkan riwayat penemuan TB anak diperoleh informasi bahwa sebagian besar responden tidak pernah menemukan terduga TB anak selama tiga bulan terakhir yaitu sebanyak 34 orang. Hal ini karena penderita $\mathrm{TB}$ anak cenderung jarang dan 
sulit ditemukan.

TB DOTS merupakan program yang direkomendasikan oleh WHO sejak tahun 1990-an. Program ini bertujuan untuk memanggulangi kasus TB yangmana tersusun atas lima komponen kunci meliputi: dukungan politik, penemuan kasus melalui pemeriksaan dahak mikroskopis, pengobatan yang standar, sistem pengelolaan dan ketersediaan obat anti TB (OAT) yang efektif, serta sistem monitoring pencatatan dan pelaporan yang baik (Kementrian Kesehatan RI, 2011). Dilihat dari riwayat sosialisasi tentang TB DOTS, sebagian besar responden menyatakan pernah mengikuti sosialisasi TB DOTS yaitu sebanyak 29 orang. Penyelenggara sosialisasi TB DOTS banyak dilaksanakan oleh Dinas Kesehatan Kota (DKK). Hal ini karena TB merupakan salah satu penyakit menular yang menjadi program prioritas oleh Dinas Kesehatan Kota (DKK) Surabaya guna mengurangi jumlah penderita TB sehingga materi tentang TB DOTS sering disosialisasikan kepada petugas kesehatan (Dedek, 2008).

\section{Pengetahuan Dokter Praktik Mandiri}

Pengetahuan merupakan hasil tahu. Hal ini terjadi setelah seseorang melakukan pengindraan pada suatu objek tertentu melalui pancaindra manusia pada suatu objek tertentu melalui indra penglihatan, pendengaran, penciuman, rasa dan raba dengan sendiri (Riyanto, 2013). Sebagian besar pengetahuan manusia diperoleh melalui mata dan telinga (Notoatmodjo, 2010). Pengetahuan merupakan domain yang sangat penting dalam membentuk tindakan seseorang (Notoatmodjo, 2012).

Berdasarkan hasil penelitian diketahui bahwa Dokter Praktik Mandiri (DPM) yang memiliki tingkat pengetahuan kurang sebanyak 21 orang. Meskipun sebelumnya, responden yang terlibat dalam penelitian ini telah mendapatkan workshop tentang "Optimalisasi Peran Dokter Praktik Mandiri (DPM) dalam penemuan Kasus TB Anak di Kota Surabaya Tahun 2017" yang diselenggarakan oleh pihak Fakultas Kesehatan Masyarakat Universitas Airlangga bekerjasama dengan Kementrian Kesehatan Republik Indonesia dan GLOBAL FUND. Namun, pelaksanaan workshop tersebut tidak memberikan dampak langsung terhadap tingkat pengetahuan Dokter Praktik Mandiri (DPM). Hal ini karena setiap responden memiliki kemampuan, wawasan dan pengetahuan yang berbeda terlebih penegakkan diagnosis TB pada anak memang cenderung sulit untuk dilakukan.

Hasil penelitian ini didukung penelitian lain yang dilakukan oleh Yovi, dkk (2015) dengan judul "Pengetahuan Dokter Umum Praktik Swasta mengenai Penatalaksanaan Tuberkulosis Paru di Kota Pekanbaru" yang menyatakan bahwa sebagian besar Dokter Umum Praktik Swasta (DUPS) memiliki tingkat pengetahuan kurang sebanyak 177 orang $(85,5 \%)$.

\section{Penemuan Terduga TB Anak}

Penemuan penderita TB anak merupakan salah satu indikator utama dalam pelaksanaan keberhasilan program penanggulangan TB dengan strategi DOTS (Widjanarko, 2006). Menurut Kementrian Kesehatan RI (2016), upaya Pemerintah dalam menemukan terduga TB anak dilakukan dengan dua cara, yaitu penemuan secara pasif dan penemuan secara aktif. Upaya yang digunakan dalam penelitian ini adalah upaya penemuan terduga TB anak secara pasif dimana anak dengan tanda dan gejala klinis TB datang ke petugas kesehatan, seperti Dokter Praktik Mandiri (DPM).

Keberhasilan penemuan terduga TB anak terbagi menjadi dua kategori yaitu menemukan dan tidak menemukan. Hasil penelitian menunjukkan bahwa sebagian besar responden tidak menemukan terduga TB anak yaitu sebanyak 31 orang. Penderita terduga TB anak jarang ditemukan karena pada saat anak berusia kurang dari tiga bulan telah mendapatkan 
imunisasi BCG sehingga risiko kecil untuk tertular penyakit TB. Hasil penelitian ini sejalan dengan penelitian yang dilakukan oleh Ahwan (2014) di Kabupaten Boyolali yang menyatakan bahwa angka penemuan kasus baru BTA positif oleh pengelola program TB Puskesmas masih di bawah target nasional $(70 \%)$ yaitu kurang dari sama dengan $16 \%$.

\section{Pengaruh Lama Praktik Mandiri terhadap Penemuan Terduga TB Anak}

Lama mengelola atau lama profesi seseorang maka konsistensi dalam perilaku di masa lalu adalah dasar perkiraan yang paling baik dari perilaku di masa depan sehingga diperkirakan bahwa semakin lama mengelola maka akan lebih baik hasil yang diperoleh (Robin, 2008). Hasil tabulasi silang antara lama praktik mandiri dengan penemuan terduga TB anak dapat diketahui bahwa penemuan terduga TB anak sebagian besar dilakukan oleh Dokter Praktik Mandiri (DPM) yang memiliki lama praktik kurang dari 10 tahun. Hasil Uji statistik menunjukkan bahwa ada pengaruh antara lama praktik terhadap penemuan terduga TB anak (Indradin, 2016).

Namun, hasil penelitian ini tidak sejalan dengan penelitian Ahwan (2014) yang menyatakan bahwa tidak ada pengaruh antara lama mengelola program TB di Puskesmas dengan angka penemuan kasus TB di Kabupaten Boyolali. Hal serupa juga disampaikan oleh Ratnasari (2015) dalam penelitiannya yang berjudul faktor-faktor yang berpengaruh pada pencapaian petugas terhadap Case Detection Rate (CDR) program TB paru di Kabupaten Rembang dengan hasil tidak ada pengaruh antara masa kerja terhadap pencapaian petugas kesehatan terhadap Case Detection Rate (CDR) pada program TB paru di Kabupaten Rembang tahun 2015. Adanya perbedaan hasil penelitian dikarenakan responden yang berpraktik kurang dari 10 tahun, cenderung tidak memiliki tugas rangkap sehingga dapat mengoptimalkan perannya selaku Dokter Praktik Mandiri (DPM) dalam menemukan terduga TB anak.

\section{Pengaruh Pengetahuan Dokter Praktik Mandiri terhadap Penemuan Terduga TB Anak}

Hasil tabulasi silang antara pengetahuan Dokter Praktik Mandiri (DPM) dapat diketahui bahwa penemuan terduga TB anak sebagian besar dilakukan temuan tersebut oleh responden yang memiliki tingkat pengetahuan kurang baik tentang TB anak yaitu sebanyak 17 orang. Hal ini didukung oleh penelitian Duhri, dkk (2012) yang menyatakan bahwa sebagian besar petugas Puskesmas berpengetahuan kurang dalam penemuan penderita TB paru yaitu sebesar $56,5 \%$.

$$
\text { Hasil Uji statistik dapat }
$$
disimpulkan bahwa tidak ada pengaruh antara pengetahuan Dokter Praktik Mandiri (DPM) tentang TB anak terhadap penemuan terduga TB anak. Namun 11 aspek pengetahuan tentang TB anak yang berpengaruh terhadap penemuan terduga TB anak adalah aspek tentang tanda dan gejala terduga TB anak dan aspek kriteria penetapan terduga TB anak. Hal ini karena setiap responden memiliki kemampuan pemahaman, analisis dan daya ingat yang berbeda terlebih tingkat pengetahuan responden yang dipengaruhi oleh banyak hal seperti: usia, pendidikan, pengalaman, informasi, dan lain-lain. Pernyataan ini didukung oleh Notoatmodjo (2012) yang menyampaikan bahwa perubahan perilaku didasari adanya perubahan atau penambahan pengetahuan, sikap atau ketrampilannya. Namun demikian, perubahan pengetahuan dan sikap ini belum merupakan jaminan terjadinya perubahan perilaku, sebab perilaku baru tersebut kadang-kadang memerlukan dukungan material dan motivasi.

Hasil penelitian ini didukung oleh penelitian Awusi, dkk (2009) dengan hasil tidak ada pengaruh yang bermakna secara 
statistik antara pengetahuan petugas TB terhadap penemuan penderita TB paru. Penelitian lain yang mendukung adalah penelitian yang dilakukan oleh Ahwan (2014) dengan hasil tidak ada pengaruh antara pengetahuan pengelola program $\mathrm{TB}$ dengan angka penemuan kasus TB di Kabupaten Boyolali.

\section{SIMPULAN}

Kesimpulan yang dapat ditarik dalam penelitian ini adalah sebagian besar responden masuk dalam golongan usia antara 36-45 tahun dengan kualifikasi tingkat pendidikan sebagai dokter umum dan telah berpraktik selama 10 tahun atau lebih di wilayah Surabaya Utara serta tidak pernah menemukan penderita TB anak selama tiga bulan terakhir dan pernah mengikuti sosialisasi tentang TB DOTS.

Dilihat dari pengetahuan responden tentang TB anak, jumlah responden yang memiliki tingkat pengetahuan kurang baik sebesar $50 \%$. Keberhasilan penemuan terduga TB anak oleh Dokter Praktik Mandiri (DPM) diketahui bahwa sebagian besar responden tidak menemukan terduga TB anak.

Berdasarkan hasil analisis dapat diperoleh informasi bahwa terdapat pengaruh antara lama praktik di wilayah Surabaya Utara terhadap penemuan terduga TB anak tidak ada pengaruh antara pengetahuan Dokter Praktik Mandiri (DPM) tentang TB anak terhadap penemuan terduga TB anak.

Saran yang dapat diberikan bagi Dinas Kesehatan adalah perlu adanya sosialisasi TB DOTS bagi Dokter Praktik Mandiri (DPM) yang dilakukan secara berkala yaitu dua kali dalam setahun dengan diutamakan materi tentang tanda gejala dan kriteria penetapan terduga TB anak serta tentang penatalaksanaan TB anak. Bagi Dokter Praktik Mandiri (DPM) diharapkan meningkatkan pengetahuan, dan komitmen dalam penemuan dan pelaporan kasus TB anak kepada Dinas
Kesehatan terkait. Bagi peneliti lain perlu adanya penelitian lebih lanjut berkaitan dengan motivasi Dokter Praktik Mandiri (DPM) terutama berkaitan dengan pelaporan dan pencatatan penemuan penderita terduga TB anak.

\section{DAFTAR PUSTAKA}

Ahwan, R. 2014. Pengaruh antara Karakteristik Individu Pengelola Program TB Puskesmas terhadap angka penemuan kasus TB di Kabupaten Boyolali. Skripsi. Universitas Muhammadiyah Surakarta.

Awusi, S., Y.D., Hadiwijoyo, Y., 2009. Faktor-faktor yang Mempengaruhi Penemuan Penderita TB Paru di Kota Palu Provinsi Sulawesi Tengah. Berita Kedokteran Masyarakat, [e-journal] Volume 25(2).

Azwar, S. 2013. Sikap Manusia: Teori dan Pengukurannya. Yogyakarta: Pustaka Pelajar

Dedek, M. 2008. Faktor Predisposing, Enabling, dan Reinforcing terhadap Penggunaan Alat Pelindung Diri dalam asuhan Persalinan Normal di Rumah Sakit Meuraxa Banda Aceh. Medan: Sekolah Pasca Sarjana Universitas Sumatera Utara

Departemen Kesehatan RI. 2009. Sistem Kesehatan Nasional. Jakarta

Departemen Kesehatan RI. 2012. Warta Tuberkulosis Indonesia Vol. 20. Jakarta:

Dinas Kesehatan Kota Surabaya. 2015. Profil Kesehatan Tahun 2015. Surabaya: Dinas Kesehatan Kota Surabaya

Dinas Kesehatan Provinsi Jawa Timur. 2014. Profil Kesehatan Provinsi Jawa Timur 2014. Jawa Timur: Dinas Kesehatan Provinsi

Duhri, A.P., Thaha, I.L.M., Ansariadi, 2012. Kinerja Petugas Puskesmas 
dalam Penemuan Penderita TB Paru di Puskesmas Kabupaten Wajo. [e-journal].

Indradin dan Irwan. 2016. Strategi dan Perubahan Sosial. 1st ed. [e-book] Yogyakarta: Deepublish.

Kartasasmita, C.B. 2009. Epidemiologi Tuberkulosis. Bandung: Fakultas Kedokteran Universitas Padjajaran

Kementrian Kesehatan RI. 2011. Pedoman Nasional Pengendalian Tuberkulosis. Edisi kedua Cetakan ke 1. Jakarta: Kementrian Kesehatan Republik Indonesia

Kementrian Kesehatan RI. 2014. Pedoman Nasional Pengendalian Tuberkulosis. Edisi kedua Cetakan ke 1. Jakarta: Kementrian Kesehatan Republik Indonesia

Kementrian Kesehatan RI. 2016. Profil Kesehatan Indonesia 2015. Jakarta: Kementrian Kesehatan Republik Indonesia

Kementrian Kesehatan RI. 2016. Petunjuk Teknis Manajemen dan Tatalaksana TB Anak. Jakarta: Kementrian Kesehatan Republik Indonesia

Lemeshow, S. 1997. Besar Sampel dalam Penelitian Kesehatan. Yogyakarta: Gadjah Mada University

Mahendradhata, Y., Utarini, A., Lazuardi, U., Boelaert, M., dan Stuyft, P.V., 2007. Private Practitioners and Tuberculosis Care Detection in Jogjakarta, Indonesia: Actual Role and Potensial. Journal Tropical Medicine and Intenational Health. [e-journal] Volume 12 (10).

Mubarak, dkk. 2007. Promosi Kesehatan: Sebuah Pengantar Proses Belajar Mengajar dalam Pendidikan. Yogyakarta: Graha Ilmu

Notoatmodjo, S. 2007. Promosi Kesehatan dan Ilmu Perilaku. Jakarta: Rineka Cipta

Notoatmodjo, S. 2010. Promosi Kesehatan Teori dan Aplikasi. Jakarta: Rineka Cipta
Notoatmodjo, S. 2012. Promosi Kesehatan dan Perilaku Kesehatan. Jakarta: Rineka Cipta

Ratnasari, D. 2015. Faktor-faktor yang Berhubungan dengan Pencapaian Petugas terhadap Case Detection Rate (CDR) pada Program TB Paru di Kabupaten Rembang. Skripsi. Universitas Negeri Semarang.

Riyanto, A., dan Budiman. 2013. Kapita Selekta Kuesioner Pengetahuan dan Sikap dalam Penelitian Kesehatan. Jakarta: Salemba medika

Robbins, S.P., dan Judge. 2008. Perilaku Organisasi. Jakarta: Salemba Empat

Sugiyono. 2012. Metode Penelitian Pendidikan Pendekatan Kuantitatif, Kualitatif, dan $R \& D$. Bandung: Alfabeta

Sugiyono. 2015. Statistika Non Parametriks untuk Penelitian. Bandung: Alfabeta

Sumartini. 2014. Penguatan Peran Kader Kesehatan dalam Penemuan Kasus Tuberkulosis BTA Positif melalui Edukasi dengan Pendekatan Theory of Planned Behaviour (TPB). [ejournal] Vol 8.: 1.

Widjanarko, B., Prabamurti, P.N., Widayat, E., 2006. Pengaruh Karakteristik, Pengetahuan dan Sikap Petugas Pemegang Program Tuberkulosis Paru Puskesmas terhadap penemuan Ssupek TB Paru di Kabupaten Blora, [ejournal] Volume 1(1).

WHO. 2015. Global Tuberculosis Report 2015 Ed. 20. Switzerland: WHO

WHO. 2016. Global Tuberculosis Report 2016. Switzerland: WHO

Yovi, I., Anggraini, D., Maulidya, D.Y., Murni, M.D., Wijaya, P.B., Putri, W., 2015. Pengetahuan Dokter Umum Praktik Swasta Mengenai Penatalaksanaan Tuberkulosis Paru di Kota Pekanbaru. J Respir Indo, [e-journal] Vol.35. 